\title{
ПСИХОЛІНГВІСТИЧНІ ОСНОВИ НАВЧАННЯ ПУНКТУАЦІї В ШКОЛІ
}

канд. пед. наук, доцент Павлюк Н. П.

Украйна, м. Рівне, Рівненський державний гуманітарний університет

DOI: https://doi.org/10.31435/rsglobal_wos/30112019/6809

\section{ARTICLE INFO}

Received: 21 September 2019

Accepted: 13 November 2019

Published: 30 November 2019

\section{KEYWORDS}

psychology, linguistic bases of punctuation training, stages of mastering knowledge, types of punctuation skills.

\begin{abstract}
In the article the question of the poetapnogo forming of mental actions is affected, maintenance of psychological operations, which lie in the basis of opening of properties and signs of basic pounctouatsiynih concepts, and also forming of pounctouatsiynih skills, is found out; the structure of mental action is described on mastering of pounctouatsiynih rules and making of skills of competent letter.
\end{abstract}

Citation: Павлюк Н. П. (2019) Psykholinhvistychni Osnovy Navchannia Punktuatsii v Shkoli. International Academy Journal Web of Scholar. 11(41), Vol.2. doi: 10.31435/rsglobal_wos/30112019/6809

Copyright: ( $) 2019$ Павлюк Н. П. This is an open-access article distributed under the terms of the Creative Commons Attribution License (CC BY). The use, distribution or reproduction in other forums is permitted, provided the original author(s) or licensor are credited and that the original publication in this journal is cited, in accordance with accepted academic practice. No use, distribution or reproduction is permitted which does not comply with these terms.

Вступ. Психологія - наука про психіку в її розвитку як усіх людей, так і кожної людини зокрема, в її прояві у різних видах діяльності. Вона вивчає процеси мислення і мовлення, спілкування між людьми, закономірності оволодіння мовленням у дитячому віці, вивчає процеси засвоєння учнями різних структурних рівнів української мови, шляхи формування особистості учня, розвиток його пізнавальної активності. У педагогічній психології досліджується і психологія засвоєння пунктуації. Психологічні дослідження розкривають процеси засвоєння матеріалу, формування пунктуаційних понять, умінь і навичок [7: 486].

Лінгвістичні основи пунктуації дають правильне розуміння цілей, завдань і значення методики пунктуації. Однак раціональне вирішення практичних завдань, розробка нових методів і прийомів навчання пунктуації лише 3 опорою на лінгвістичне обгрунтування цього розділу рідної мови не можливе без чіткого розуміння вчителем психічних закономірностей формування в учнів пунктуаційних умінь і навичок. У з'ясуванні взаємозв'язку таких понять i полягає мета нашого дослідження.

Так, ще К.Д. Ушинський, високо цінуючи роль психологічних знань педагога, відзначав, що в доборі методичних прийомів навчання необхідно “визначити психічний закон, на якому базується те чи інше педагогічне правило"[ 11: 486].

Результати дослідження. Оскільки, пунктуація і синтаксис спрямовані на засвоєння синтаксичних явищ, законів побудови речень і пунктуаційних правил, що спираються на них, це процес абстрактний і узагальнений, завдання дослідників-методистів полягає в тому, щоб розглянути особливості внутрішньої психологічної дії школярів у процесі засвоєння пунктуаційних знань. Виявлення психологічних i лінгводидактичних засад вироблення пунктуаційних умінь $\epsilon$ надзвичайно актуальним, спрямованим на формування мовної особистості та нерозробленістю цього питання у лінгводидактичній літературі.

3 вищезазначеного визначимо низку завдань нашого дослідження:

- на основі теорії поетапного формування розумових дій з'ясувати зміст психологічних операцій, які лежать в основі розкриття властивостей і ознак основних пунктуаційних понять, а також формування пунктуаційних навичок; 
- описати особливості розумових дій, спрямованих на засвоєння пунктуаційних правил і вироблення навичок грамотного письма.

У психологічному плані навчання - це форма активності, дії, направленої на засвоєння знань, умінь, навичок, розвиток здібностей, сприйняття, пам'яті, мислення, мови та інших процесів пізнання. Будь-які знання не можуть бути засвоєними чи збереженими поза дією того, що вивчається. Знання ніколи не можна дати у готовому вигляді: вони завжди засвоюються через включення їх у ту чи ту діяльність. Зважаючи на те, що знання - це лише образи предметів, явищ, дій матеріального світу, вони ніколи не існують у людській голові поза будьякою діяльністю, поза окремими діями. Тому в основі психолого-педагогічної теорії навчання лежить діяльнісний підхід, який стосується процесу засвоєння нових знань. Прихильниками діяльнісної теорії навчання як процесу пізнання є О.М. Леонтьєв, Д.Б. Ельконін, В.В. Давидов, П.Я. Гальперин, Н.Ф. Тализіна та інші. Вчені розглядають пізнавальну діяльність як перехід із плану суспільного досвіду в індивідуальний і, відповідно, своїм завданням вважають вивчення законів перетворення явищ суспільної свідомості в індивідуальну, щоб, використовуючи всі психологічні знання з цього питання, оптимізувати навчальну діяльність. Центральна ланка теорії - це дія як одиниця діяльності навчання. Послідовне виконання певних видів діяльності в межах однієї системи приводить учня до нових знань і вмінь. “Домовимся називати навчанням, - пише П.Я. Гальперин, - будь-яку діяльність, оскільки в кінцевому результаті у виконавця формуються нові знання, і вміння набувають нових якостей” [3: 15].

Пізнавальні дії моделюються у зовнішній матеріальній чи матеріалізованій формі, в якій існують і знання, що мають бути засвоєними (наприклад, схематична модель речення як форма “матеріалізації” ознак понять, що формуються), включаються до складу цісї дії. Таким чином, засвоєння знань і формування адекватної їм системи розумових дій - це єдиний процес, оскільки вміння функціонувати у зовнішньому (розумовому) плані формуються на основі зовнішніх предметних дій. Предметна дія і думка, що ії виражає, становлять кінцеві, генетично пов'язані, але початково протилежні ланки одного процесу поступового перетворення матеріальної дії в ідеальну - ії інтеріоризацію (перехід із зовні всередину) [3].

Основи теорії інтеріоризації, тобто перетворення зовнішньої матеріальної діяльності у діяльність внутрішню, психологічну, були закладені у кінці 40-их років ХХ століття у працях Л.С. Виготського, О.М. Леонтєьва， С. Л. Рубінштейна. У подальшому принципи єдності психічної і практичної діяльності отримали розвиток у працях П.Я. Гальперина, який розглядав процес перетворення зовнішньої матеріальної діяльності у внутрішню, психічну як процес закономірної заміни певних етапів. Розроблена вченим психолого-педагогічна теорія навчання отримала назву теорії поетапного формування розумових дій.

Спираючись на положення діяльнісної теорії засвоєння знань, П.Я. Гальперин виділяв такі етапи і співвідносні їм форми дій: матеріальний (чи матеріалізований), гучномовний (чи зовнішньомовний) і розумовий [3].

На першому етапі відбувається засвоєння змісту дії з матеріалізованим об'єктом розкривається склад операцій, їх послідовність. Наприклад, запропонувавши граматичну схему речення, вчитель допоможе виділити істотні ознаки пунктограм.

На етапі зовнішньомовної дії (коли об'єкт дії представлений у формі усної чи писемної мови) вона ще доступна об'єктивному спостереженню, але вже набуває характеру теоретичного, ідеального.

Третій етап - етап реалізації дій у внутрішньому мовленні. Структурними елементами розумової форми дії є уявлення, поняття, операції, які формуються “в собі”. Можливість виконання дії повністю в розумовій формі означає, що вона пройшла весь шлях інтеріоризації, змінилася із зовнішньої на внутрішню [10:59].

На цьому етапі, - пише Н. Ф. Тализіна, - дія дуже швидко набуває автоматичного плину, стає недоступною для самоспостереження. Тепер це вже акт думки, де процес схований, а свідомості розкривається лише продукт цього процесу [10:108].

Ми розглянули загальні психологічні закономірності засвоєння знань школярами залежно від ступеня узагальненості у вигляді орфографічного чи пунктуаційного правила. Вміння самостійно оволодівати міцними пунктуаційними навичками - це продукт процесу пізнання, певних етапів розумових дій суб'єкта представлених у згорнутому вигляді. 
Інтелектуальні дії, які передбачають вибір і розташування розділових знаків на письмі, називаються пунктуаційними вміннями [1:195].

Пунктуаційні вміння складаються з таких інтелектуальних операцій:

1) попередження змістового відрізка, необхідного для вираження додаткового значення у реченні; передбачення нової думки і ії̈ зв'язку з попередньою у тексті ;

2) усвідомлення структури конструкції, що створюється, характеру і місця у ній змістового відрізка;

3) визначення у реченні місця розділового знаку і вибір потрібного;

4) розташування розділового знаку [1: 196].

М.Т. Баранов виділяє чотири види пунктуаційних умінь:

1) уміння знаходити змістові відрізки, що потребують пунктуаційного оформлення розділовими знаками, спирається на пізнавальні ознаки змістових відрізків;

2) уміння розташовувати розділові знаки у співвідношенні з вивченими пунктуаційними правилами складається з низки пунктуаційних дій: знайти змістовий відрізок і з'ясувати його природу, встановити границі; з'ясувати місце змістового відрізка в комунікативній одиниці; зробити вибір розділового знаку; поставити розділовий знак;

3) уміння обгрунтувати вибір місця розділового знаку поєднує знаходження змістового відрізка, з'ясування його місця, значення та інтонації;

4) уміння знаходити пунктуаційні помилки [1:196].

Проблеми формування пунктуаційних умінь розглядалися М.Т. Барановим, В.В. Гадаловою, Г.Г. Граник, Л.Т. Григоряном та іншими.

Можна виявити кілька шляхів формування пунктуаційних умінь. Найбільш традиційні пропонують Г.І. Блинов, Л.Т. Григорян, А.Ф. Ломизов, Ю.С. Пічугов та інші. Цей шлях зумовлюється взаємозв'язком навчання синтаксису і пунктуації: від синтаксичних понять до пунктуаційних правил. Із цього випливає, що в основі пунктуаційного вміння лежить уміння виконувати пунктуаційний аналіз речення: знаходити в його будові такі елементи та ї поєднання, встановлювати такі відношення між ними, коли пізнається структура, що схематично наявна у правилі [2:24].

У роботі над формуванням пунктуаційних умінь виділяють три ступені: 1) підготовча робота (основна мета - опанування синтаксичної основи пунктуаційного вміння); 2) робота над формулюванням правила; 3) робота над застосуванням правила [8:44].

У змісті підготовчої роботи з синтаксису А.Ф. Ломизов відзначає: “До вивчення конкретного пунктуаційного правила учні повинні, по-перше, осмисллено і міцно засвоїти всі синтаксичні поняття, на які фігурують у правилі, i, по-друге, вільно аналізувати ту синтаксичну конструкцію, з якою це правило пов'язане" [6:18].

Робота над формулюванням правила включає два етапи: 1) осмислення пунктуаційного правила; 2) запам’ятовування пунктуаційного правила.

Осмислення пунктуаційного правила дає право учням не лише правильно розуміти його загальний граматичний та пунктуаційний зміст, але і чітко з'ясовувати, за яких умов ставиться чи не ставиться розділовий знак у тій синтаксичній конструкції, про яку говориться у правилі [8:44].

Суть запам'ятовування полягає у закріпленні тимчасових зв'язків, які утворюються у процесі сприймання нового матеріалу в корі великих півкуль головного мозку [6: 67]. Учні не запам'ятовують дослівне формулювання правила, а лише ті умови, які вирішують питання про розташування розділового знаку.

Застосування правила - складний розумовий процес, пов'язаний зі встановленням умов пунктуаційної норми, виділенням логічних операцій та визначенням їх послідовності [2:51]. Використання правила - це значить побачити і виділити ті синтаксичні конструкції, для пунктуаційного оформлення яких існує правило, вміти відмежувати ці речення від інших, що схожі з ними.

Для того, щоб школярі навчилися застосовувати правила для вирішення пунктуаційних завдань, вони повинні: 1) знати ознаки синтаксичних конструкцій, про пунктуаційне оформлення яких повідомляе правило; 2) володіти прийомами, 3 допомогою яких розпізнаються речення; 3) розуміти і пам'ятати умови, за яких виявляється пунктуаційна норма; 4) вміти зіставити у реченні правило з пунктуаційною ситуацією, що аналізується; вміти підвести пунктуаційне поняття, що розглядається, під певне правило і вирішити питання про розташування розділового знаку; 5) вміти перевірити правильність вирішення пунктуаційного завдання [8:46]. 
Характер розумової діяльності під час застосування правил різнобічний і складний: учень повинен за співвідношенням ознак з'ясувати синтаксичну одиницю, дібрати пунктуаційне правило, зіставити умови його дії з ознаками конкретної будови і вирішити питання про вживання розділового знаку.

Робота над застосуванням правила повинна здійснюватися за певною системою пунктуаційних вправ.

За такого підходу до формування пунктуаційних умінь у свідомості учнів закладається уявлення про залежність пунктуації від синтаксису, що впливає на рівень пунктуаційної грамотності школярів.

Інший шлях формування пунктуаційних умінь пропонують Г.Г. Граник, М.Я. Мікулинська та інші: формування пунктуаційних умінь будується на уявленні про психологічну природу навички грамотного письма.

Уміння розглядається Г. Г. Граник як дія, що може бути виконана людиною у різнних умовах. Ця дія-уміння має особливу орієнтовну частину, що складається з низки операцій, які змінюються. Забезпечує побудову орієнтовної частини дії-уміння загальний розумовий прийом [4:104]. Під прийомом розумової роботи подається система мисленнєвих операцій, здійснення яких дозволяє застосовувати певні знання для вирішення завдань [5:3]. Загальні прийоми розумової роботи - це такі прийоми, здійснення яких дозволяє вирішити всі пунктуаційні завдання, що регулюються синтаксичними правилами [8:3]. Загальний прийом складається 3 таких операцій: 1) розпізнавання у реченні деяких вихідних синтаксичних елементів; 2) розумове поєднання елементів у правилоподібних семантико-синтаксичних блоках, що розділяються реченнями на пунктуаційно оформлені частини; 3) визначення необхідних пунктуаційних знаків [4:104].

Для вироблення вмінь виконувати вказані операції мають бути сформовані окремі прийоми розумової роботи. Прийоми, здійснення яких дозволяє вирішити всю сукупність пунктуаційних завдань будь-якого одного типу [5:3]. Порядок формування окремих операцій, які сформовані у більш чи менш згорнутому вигляді, залежить від послідовності вказаних операцій у загальному прийомі. Кожен із них формується під час спеціального навчання та тренування. Здійснення такого тренування, на думку Г.Г. Граник, включає створення системи вправ, що повинна бути спрямована на формування певної низки операцій. У створенні такої системи особлива увага надається вправам, які сприяють виробленню можливості виявляти орієнтовні напрямки, що розширюють простір попередження і обсяг утримання елементів, $\mathrm{i}$ правиловідповідних семантико-синтаксичних блоків речення.

Щоб забезпечити вільну, швидку зміну операційного складу дії, що виконується за різних умов, пропонується з самого початку тренування, після побудови зі школярами певного прийомуінструкції у застосуванні правила, систематично чергувати види письмових робіт [4:110].

Такий спосіб формування пунктуаційних умінь, запропонований Г. Г. Граник, яка не розглядає пунктуацію як самостійну систему, що функціонує в мові.

М. Т. Баранов запропонував третій шлях формування пунктуаційних умінь: від загальних уявлень про значення пунктуації через осмислення сутності таких понять, як змістовий відрізок і функція розділового знаку, до оволодіння умовами вибору розділових знаків.

Докладно розробивши поняття “змістовий відрізок”, М. Т. Баранов дійшов до наступних методичних висновків: важливою умовою оволодіння пунктуаційною грамотністю $\epsilon$ формування в учнів уміння знаходити у реченні і тексті змістові відрізки, що потребують пунктуаційного оформлення. Це вміння він називав пунктуаційною пильністю [1:18]. Формування пунктуаційної пильності він пропонує базувати, починаючи вже з V класу, на поняттях змістовий відрізок, позиція змістового відрізка у реченні, розпізнавальні ознаки змістового відрізка, умови вибору розділового знаку.

Пунктуаційна пильність $є$ базою для формування вміння пунктуаційно правильно формувати речення і текст у співвідношенні з вивченим пунктуаційним правилом. Навчити школярів правильно оформляти тексти - це, як відзначає М.Т. Баранов, значить навчити їх, по-перше, знаходити межі змістових відрізків, по-друге, вибирати з низки розділових знаків потрібний [1:21].

М. Т. Баранов пропонує наступну послідовність пунктуаційних дій:

1) знайти змістовий відрізок і з'ясувати його природу;

2) визначити місце змістового відрізка у реченні; 
3) зробити вибір потрібного розділового знаку;

4) поставити розділовий знак [ 1:23].

Навчання послідовності пунктуаційних дій пропонується проводити у процесі показу застосування пунктуаційного знаку на практиці, тобто після ознайомлення з умовами вибору розділового знаку та співвідносним пунктуаційним правилом.

Навчання учнів пунктуаційної дії складається з наступних видів роботи:

а) зразка роздумів школярів;

б) колективного застосування послідовності пунктуаційної дії;

в) самостійного застосування учнями послідовності пунктуаційної дії [1 :24].

Закріплюється послідовність пунктуаційних умінь під час виконання різних вправ.

А.Ф. Ломизов, досліджуючи психологічні основи пунктуації, вказує на необхідність вироблення в учнів певних прийомів розумової дії. Для формування і закріплення навичок пунктуації велике значення, на його думку, має організація мислительної діяльності школярів у процесі застосування конкретного пунктуаційного правила [6:102]. Тому повне оволодіння прийомами пунктуаційного аналізу не можливе без урахування певних психологічних процесів.

Пунктуаційна навичка виробляється на основі вміння свідомо аналізувати граматичну будову речення і відчувати, розпізнавати особливості синтаксичної будови, які служать обгрунтуванням у правилах пунктуації. Це вміння досягається такої досконалості, коли потрібні для пунктуації логікограматичні особливості розпізнаються учнем автоматично, як у період прослуховування і запису під диктовку речень, так і в процесі оформлення своїх власних думок на письмі.

Наприклад, під час розташування першого розділового знаку в складносурядному реченні Берізки, які були посаджені мною поблизу паркану, виросли і стали тепер високими деревами (3 журналу). Учень спирається на зовнішні ознаки (підрядний сполучник може бути “сигналом") i відокремлює комою перше слово головного речення неусвідомлено. Розташування другого знаку потребує участі свідомості: логіко-граматичного аналізу речення, 3'ясування предикативних меж його частин і таке інше. На початковому етапі формування пунктуаційної навички учень виконує дії у матеріалізованій формі, працюючи над синтаксичною моделлю висловлювання. Школяр спочатку виділяє основи речення (здійснює частковий синтаксичний розбір); малює схему даної конструкції, визначає межі предикативних частин; і лише зробивши цю складну розумову операцію, - із впевненістю розташовує розділовий знак. Коли ж у процесі виконання тренувальних вправ у школяра всі ці матеріалізовані дії протікають у внутрішньому плані, “в собі” (явище інтеріоризації), тоді можна говорити про міцну пунктуаційну навичку, що вже сформувалася.

Таким чином, для правильного написання недостатньо завчити правило і вміти його відтворити, необхідно його зрозуміти, сприйняти те граматичне узагальнення, яке наявне у вигляді пунктуаційного правила. Тому формування і функціонування пунктуаційної навички можливе лише за наявності певних синтаксичних і пунктуаційних узагальнень.

Уточнюємо: у психології узагальнення - це мисленнєва операція, значення якої в об’єднанні явищ за загальними істотними ознаками, що виділяються у результаті абстрагування [9: 13].

Висновки. Можна зробити такі висновки:

- удосконалення процесу навчання пунктуації не можливе без урахування внутрішніх психічних закономірностей засвоєння школярами пунктуаційних знань, психологічних особливостей формування пунктуаційних умінь і навичок, а також умілої організації мисленнєвої діяльності учнів у процесі застосування конкретних пунктуаційних правил;

— опора на теорію інтеріоризації - переходу “матеріалізованої” дії в ідеальну (внутрішню) дозволяе прискорити процес формування пунктуаційних умінь i навичок, коли в якості “матеріалізованої" моделі абстрактних понять, синтаксичних явищ, пунктуаційних узагальнень учні оперують граматичними схемами та іншими умовно-графічними позначеннями;

- основою оволодіння правописними навичками, у тому числі й пунктуаційними, $\epsilon$ навчальна діяльність, послідовне виконання певних видів якої у межах однієї системи приводить учня до нових знань та умінь.

Таким чином, психологічне обгрунтування процесу навчання пунктуації дає можливість оптимізувати процес формування пунктуаційних навичок, забезпечити широке перенесення пунктуаційних узагальнень на новий мовний матеріал, підвищити рівень граматичних знань $\mathrm{i}$ пунктуаційних умінь. 


\section{ЛІТЕРАТУРА}

1. Баранов Е.А. Методика русского языка / Е.А.Баранов, Л.Ф.Боженкова, В.И.Лебедев. - М.: Просвещение, 1974. - 368 с.

2. Блинов Г.И. Методика изучения пунктуационных правил / Г.И.Блинов. - М. : Просвещение, 1972. - 208 с.

3. Гальперин П.Я. Формирование знаний и умений на основе теории поэтапного усвоения действий / П.Я. Гальперин. - М.: АПНРСФСР, 1968.

4. Граник Г.Г. Психологические основы пунктуационных упражнений / Г.Г. Граник // Вопросы психологии. - 1980. - №4.

5. Граник Г.Г. Психологические принципы построения школьнного курса синтаксиса и пунктуации: автореф. дис. д-ра псих. наук / НИИ / Г.Г. Граник. - М. - 1976.

6. Ломизов А.Ф. Трудные вопросы методики пунктуации: пособие для учителя / А.Ф.Ломизов. - М.: Просвещение, 1975. - 159 с.

7. Наумчук М.М. Словник-довідник основних термінів і понять з методики української мови : навчальнометодичний посібник / М.М.Наумчук, Л.П.Лушпинська. - Тернопіль: Астон, 2003. - 132c.

8. Пичугов Ю.С. Формирование и совершенствование пунктуационных навыков / Ю.С.Пичугов // Работа над орфографическими и пунктуационными навыками: сб. под ред. Ю.С. Пичугова, В.М. Шаталовой. - М.: НИИ СиМО. - 1979.

9. Текучов Ю.С. Использование системы условно-графических обозначений при изучении пунктуации / Ю.С.Текучов. - М., 1974. - 128 с.

10. Талызина Н.Ф. Управление процесом усвоения знаний / Н.Ф.Талызина. - М., 1975. - 344 с.

11. Ушинский К.Д. Избранные педагогические сочинения / К.Д.Ушинский. - М., Учпелгиз, 1945. - 567c. 